\title{
IMPROVING SPACE PROJECT COST ESTIMATING WITH ENGINEERING MANAGEMENT VARIABLES
}

\author{
Joseph W. Hamaker, Engineering Cost Office, NASA Marshall Space Flight Center
}

\begin{abstract}
Current space project cost models attempt to predict space flight project cost via regression equations, which relate the cost of projects to technical performance metrics (e.g. weight, thrust, power, pointing accuracy etc.). This paper examines the introduction of engineering management parameters to the set of explanatory variables. A number of specific engineering management variables are considered and exploratory regression analysis is performed to determine if there is statistical evidence for cost effects apart from technical aspects of the projects. It is concluded that there are other non-technical effects at work and that further research is warranted to determine if it can be shown that these cost effects are definitely related to engineering management.
\end{abstract}

\section{Introduction}

Predicting the cost of future projects is not an exact science. There are far too many variables involved and many of these are not predictable with any precision before the project begins. This is especially true in the venue of NASA space projects that are almost always on the cutting edge of technology. Nevertheless, the requirement remains for approaches which can give some indication of the cost of a space project before full commitment is made. Current space cost models employ cost estimating relationships (CERs) based on historical projects, which regress technical parameters of these past projects against the known cost of the past projects. This approach, the current state of the art, works marginally well. But the CERs typically have large variance, which leads to wide confidence intervals around any estimate.

Most conventional thinking on this subject has followed the line that this variance in the regressions has been due to the technical parameters not being sufficiently addressed in terms of fully describing the complexities of the projects. However, it is the thesis of this paper that some significant part of the variance in the historical cost of NASA projects could be caused by engineering management differences between the projects that is not being captured in the traditional cost models. Using previous work examining NASA's engineering management history (Hamaker, 1999) this paper will outline what engineering management culture changes have occurred over NASA's history and perform an exploratory analysis to attempt to determine if there is statistical evidence that improvements in management culture could be having an effect on project costs.

\section{Background}

The referenced previous work qualitatively assessed various engineering management initiatives throughout NASA's history in terms of their potential for improving productivity. The initiatives were categorized and examined in terms of their effectiveness on aerospace programs. The work surfaced three distinct eras of NASA engineering management philosophy as depicted in Exhibit 1: (1) The newly formed NASA of the 1960's (termed the "Apollo Era"), (2) the maturing NASA of the 1970's through the 1980's (termed the "Shuttle Era") and finally (3) the NASA of the 1990's attempting to restructure itself under the stewardship of the NASA Administrator Dan Goldin (termed the "Goldin Era"). For each of these eras, the previous study examined the 13 separate engineering management criteria (listed in exhibit 1) and characterized the NASA organization against these criteria.

\section{Extension of Previous Work}

This paper extends the work summarized in Exhibit 1. Here we will search for statistical evidence that the engineering management improvements claimed have provided any measurable reductions in NASA project costs. Eventually, this must be done at a very detailed level-i.e. at the individual project level by researching and rating each of the above 13 engineering management criteria for each project in the data base-see Recommendations for Further Study below. However, before undertaking the massive job of researching and rating such a large number of variables for a number of past projects, this paper performs the exploratory phase of the work by taking the shortcut of capturing the effects of engineering management improvement trends via the introduction of a time variable into the regression models used to predict NASA project cost. If there is any underlying improvement occurring in management over the 3 eras as discussed above, then it should be demonstrable with a negative slope on cost versus time. Because any cost decreases over time could just as well be attributable to a loosening of requirements on technical specifications for NASA projects (e.g. perhaps projects are being reduced in scale or complexity) the analysis will also include the necessary technical variables as well. Thus the inclusion of the technical variables can be used as a control and the analysis will search for cost improvements over time holding the technical requirements constant. 
Exhibit 1: Engineering Management Criteria

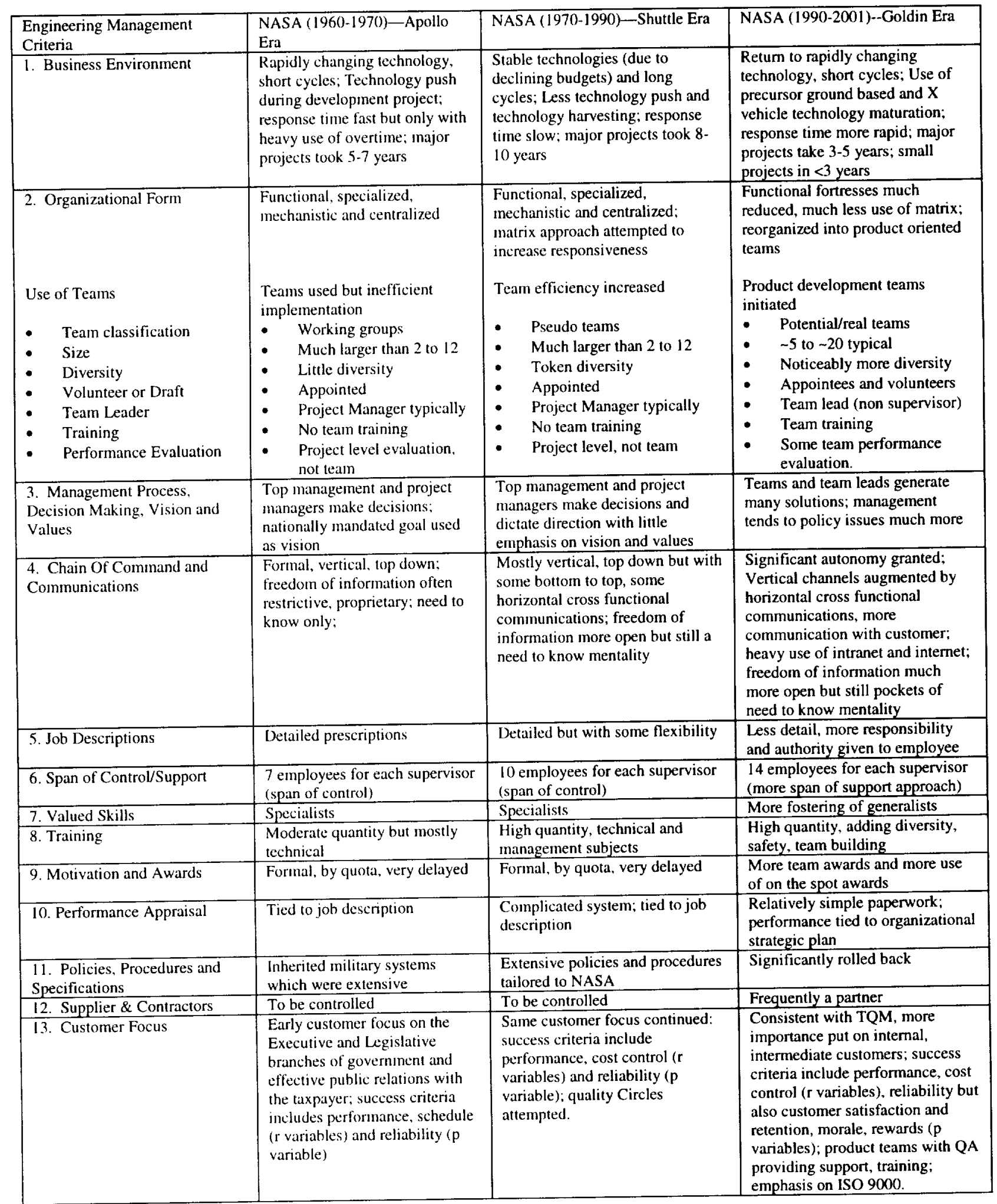




\section{Methodology}

The methodology for this initial exploratory analysis is to first develop a regression equation for predicting NASA space project cost using only technical parameters. Once a suitable technical parameter cost estimating (CER) equation has been derived, a time variable (as a proxy variable for engineering management improvement trends) will be introduced to determine if additional predictive power is observed and if the trend is negative with respect to time (i.e. a negative coefficient on time). If so, this will indicate that further research is merited to more precisely quantify the effect of the 13 engineering management variables on individual specific projects in the database.

\section{Regression Analysis Using Technical Variables Only} The NASA NAFCOM (NASAdatabase (NAFCOM, 1999) was examined to obtain project level cost and technical metrics for a substantial number of historical NASA projects. The NAFCOM database is NASA's main repository of normalized cost and technical information on historical projects for use by the Agency's cost estimating community. Exhibit 2 provides the data that was extracted from the NAFCOM database for this analysis:

The data table includes variables that that have been observed to yield good predictor equations in the past and the additional variable for time (launch year). The variables are:

- Project cost, the dependent variable, expressed in millions of 1999 dollars and transformed to natural logs due to the wide variance) and abbreviated as $\operatorname{Ln}$ Cost).

- Dry spacecraft weight in pounds (transformed to natural logs due to the wide variance) and abbreviated as $\mathrm{LnWt}$.

- Number of structural materials utilized (e.g aluminum only $=1$, aluminum + titanium $=2$, aluminum + titanium + composites $=3$, etc.) and abbreviated as NumMatls.

- Number of deployable structures, using a dummy variable, where each type of deployable is counted as 1 (; e.g. 1 antenna +1 solar array $=$ 2,3 antennas +2 solar arrays $=2,1$ solar array + 1 antenna +1 sensor boom $=3$, etc.) and abbreviated as NumDeploy.

- Type of power generation, abbreviated as Generate, using a dummy variable where

$$
\begin{array}{ll}
\circ & \text { None }=1 \\
\circ & \text { Silicon solar arrays }=2 \\
\circ & \text { Gallium Arsenide solar arrays }=3 \\
\circ & \text { Fuel cells }=3 \\
\circ & \begin{array}{l}
\text { Radioactive } \\
\text { (RTGs) }=4
\end{array} \text { Thermal Generators }
\end{array}
$$

- Battery type, abbreviated as Battery, using a dummy variable, where:

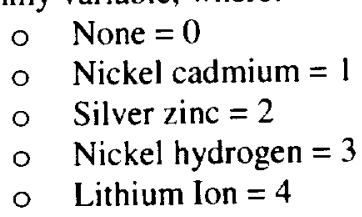

- Communications and Data Handling maximum data rate capability in kilobits per second (transformed to natural logs due to the wide variance) and abbreviated as LnDataRate

- Type of thermal control, abbreviated Thermal where

$$
\text { - Passive }=1
$$$$
\text { - } \text { Active }=2
$$

- Type of Attitude Control, abbreviated Control, using a dummy variable, where

$$
\begin{array}{ll}
\circ & \text { None }=0 \\
\text { Spin stabilized }=1 \\
\circ & \text { Despun section }=2 \\
\circ & \text { Gravity gradient }=2 \\
\circ & 3 \text { axis controlled }=3
\end{array}
$$

- Type of Guidance, Navigation and Control sensors, abbreviated Sensors, using a dummy variable, where

$$
\begin{array}{ll}
\circ & \text { None }=0 \\
\circ & \text { Sun sensors }=2 \\
\circ & \text { Earth horizon sensors }=3 \\
\circ & \text { Star trackers }=4
\end{array}
$$

- Type of Reaction Control, abbreviated Reaction, using a dummy variable, where

$$
\begin{array}{ll}
\circ & \text { None }=0 \\
\circ & \text { Monopropellant }=1 \\
& \text { Bi-propellant }=2 \\
& \text { Dual mode (mono-prop and bi- } \\
\text { prop) }=3
\end{array}
$$

- Human rated, abbreviated Human, using a dummy variable where

$$
\begin{array}{ll}
\text { - Not human rated }=1 \\
\text { Human Rated }=2
\end{array}
$$

- Launch year, transformed to Launch Year less 1960 to convert to 2 a digit metric and abbreviated as Year-1960.

First, Best subsets regression was used to as an efficient way to select a group of promising CERs. The results from the best subsets regression are shown in Exhibit 3. The $\mathrm{Cp}$ statistic is used as a criterion where we look for models where $\mathrm{Cp}$ is small and is also close to $p$ (where $p$ is the number of parameters in the model including the intercept). If the model is adequate (i.e., fits the data well), then the expected value of $C p$ is approximately equal to $p$. 
Exhibit 2. Database for Analysis

\begin{tabular}{|c|c|c|c|c|c|c|c|c|c|c|c|c|c|c|c|c|c|}
\hline Project & $\begin{array}{c}\text { Project } \\
\text { Cost } \\
\text { (1999\$M) } \\
\text { Cost }\end{array}$ & LnCost & $\begin{array}{r}\text { Dry } \\
\text { Wt. } \\
\text { (IDs) } \\
\text { Weight } \\
\end{array}$ & & $\begin{array}{l}\text { Number } \\
\text { Struct. } \\
\text { Malis } \\
\text { NumMalls }\end{array}$ & $\begin{array}{l}\text { Number } \\
\text { Deploy } \\
\text { Struct. } \\
\text { NumDep }\end{array}$ & $\begin{array}{c}\text { Type } \\
\text { Power } \\
\text { Generate } \\
0=\text { none } \\
\text { 1=Si } \\
\text { 2=GaAs } \\
\text { 3=Fuel cell } \\
4=\text { RTGS } \\
\text { Generate }\end{array}$ & $\begin{array}{c}\text { Type of } \\
\text { Battery } \\
0=\text { none } \\
1=\mathrm{NiCd} \\
2=\mathrm{AgZn} \\
3=\mathrm{NiH} \\
4=L i \text { ilon } \\
\text { Battery }\end{array}$ & $\begin{array}{c}\text { Comm } \\
\text { Data } \\
\text { Rate } \\
\text { (kbps) } \\
\text { Data }\end{array}$ & LnData & $\begin{array}{l}\text { Type of } \\
\text { Thermal } \\
\text { Control } \\
\text { 1=Passive } \\
\text { 2=Active } \\
\text { Thermal }\end{array}$ & $\begin{array}{c}\text { Type of } \\
\text { Attitude } \\
\text { Control } \\
0=\text { None } \\
\text { 1=Spin } \\
\text { 2=Despun } \\
2=\mathrm{GG} \\
3=3 \text { Axis } \\
\text { Conitrol }\end{array}$ & $\begin{array}{c}\text { Type of } \\
\text { G\&N } \\
0=\text { None } \\
1=\text { Sun } \\
2=\text { Horizon } \\
3=\text { Star } \\
\text { Sensors }\end{array}$ & $\begin{array}{c}\text { Type of } \\
\text { Reaction } \\
\text { Control } \\
1=\text { Mono } \\
2=\text { BiProp } \\
3=\text { Dual } \\
\text { Beaction }\end{array}$ & $\begin{array}{c}\text { Human } \\
\text { Rated } \\
1=\text { No } \\
2=\text { Yes } \\
\text { Human }\end{array}$ & $\begin{array}{l}\text { Launch } \\
\text { Year }\end{array}$ & $Y_{[-1960}$ \\
\hline$\frac{\text { Project }}{\text { ACTS }}$ & $\frac{\text { Cost }}{535}$ & $\frac{\operatorname{LnCost}}{6.283}$ & $\frac{\text { Weight }}{2684}$ & $\frac{\operatorname{Ln} W I}{7.895}$ & $\frac{\text { NumMalls }}{1}$ & $\frac{\text { NumDep }}{8}$ & $\frac{\text { Generate }}{1}$ & $\frac{\text { Battery }}{1}$ & $\frac{\text { Data }}{220000}$ & $\frac{\text { Lndala }}{12.301}$ & $\frac{2}{2}$ & $\frac{3}{3}$ & 2 & 1 & 1 & $\overline{1993}$ & $\frac{10+108 x}{33}$ \\
\hline AE-3 & 69 & 4.228 & 780 & 6.659 & 1 & 0 & 1 & 1 & 131 & 4.875 & 2 & 2 & 2 & 1 & 1 & 1973 & 13 \\
\hline AEM-HCMM & 18 & 2.889 & 185 & 5.220 & 1 & 2 & 1 & 1 & $B$ & 2.079 & 2 & 3 & 2 & 1 & 1 & 1978 & 18 \\
\hline $\begin{array}{l}\text { AMPTE } \\
\text { ALEXIS }\end{array}$ & 39 & 3.673 & 280 & 5.635 & 2 & 1 & 1 & 1 & 211 & 5.352 & 2 & 1 & 1 & 2 & 1 & 1984 & 24 \\
\hline $\begin{array}{l}\text { ALEXIS } \\
\text { Apollo CSM }\end{array}$ & 4 & 1.479 & 70 & 4.248 & 2 & 1 & 1 & 1 & 750 & 6.620 & 1 & 1 & 2 & 0 & 1 & 1993 & 33 \\
\hline $\begin{array}{l}\text { Apollo CSM } \\
\text { Apollo LM }\end{array}$ & 9497 & 9.159 & 31280 & 10.351 & 2 & 3 & 3 & 1 & 51 & 3.932 & 2 & 3 & 0 & 1 & 2 & 1968 & 8 \\
\hline $\begin{array}{l}\text { Apollo LM } \\
\text { ATS-1 }\end{array}$ & 6511 & 8.781 & 8071 & 8.996 & 2 & 4 & 0 & 2 & 51 & 3.932 & 1 & 3 & 0 & 1 & 2 & 1968 & $B$ \\
\hline $\begin{array}{l}\text { ATS-1 } \\
\text { ATS-5 }\end{array}$ & 154 & 5.034 & 526 & 6.265 & 1 & 0 & 1 & 1 & 1 & 0.000 & 1 & 1 & 0 & 1 & 1 & 1966 & 6 \\
\hline $\begin{array}{l}\text { ATS-5 } \\
\text { ATS-6 }\end{array}$ & $\begin{array}{l}198 \\
361\end{array}$ & $\begin{array}{l}5.288 \\
5.889\end{array}$ & $\begin{array}{c}755 \\
2535\end{array}$ & $\begin{array}{l}6.627 \\
7.838\end{array}$ & $\begin{array}{l}1 \\
3\end{array}$ & 1 & 1 & 1 & 1 & 0.000 & 2 & 1 & 2 & 1 & 1 & 1969 & 9 \\
\hline $\begin{array}{l}\text { ATS- } 6 \\
\text { Centaur-D }\end{array}$ & $\begin{array}{c}361 \\
1962\end{array}$ & $\begin{array}{l}5.889 \\
7.581\end{array}$ & 7674 & $\begin{array}{l}7.838 \\
8.946\end{array}$ & $\begin{array}{l}3 \\
1\end{array}$ & $\begin{array}{l}5 \\
0\end{array}$ & 1 & 1 & 1 & 0.000 & 2 & 3 & 2 & 1 & 1 & $\begin{array}{l}1974 \\
1966\end{array}$ & \\
\hline Centaur-G' & 678 & 6.519 & 12920 & 9.467 & $\begin{array}{l}1 \\
2\end{array}$ & $\begin{array}{l}0 \\
1\end{array}$ & 0 & 2 & 1 & 0.000 & $\begin{array}{l}1 \\
1\end{array}$ & $\begin{array}{l}3 \\
3\end{array}$ & $\begin{array}{l}1 \\
3\end{array}$ & 1 & $\begin{array}{l}1 \\
1\end{array}$ & $\begin{array}{l}1966 \\
1985\end{array}$ & $\begin{array}{c}6 \\
25\end{array}$ \\
\hline COBE & 121 & 4.793 & 4320 & 8.371 & 1 & $\begin{array}{l}1 \\
6\end{array}$ & $\begin{array}{l}0 \\
1\end{array}$ & $\begin{array}{l}2 \\
1\end{array}$ & $\begin{array}{l}1 \\
4\end{array}$ & $\begin{array}{l}0.000 \\
1.386\end{array}$ & 2 & 3 & 2 & 1 & 1 & 1989 & $\begin{array}{l}25 \\
29\end{array}$ \\
\hline CRAES & 81 & 4.393 & 2876 & 7.964 & 1 & 2 & 1 & 1 & 256 & 5.545 & 2 & 1 & 2 & 1 & 1 & 1990 & $\begin{array}{l}29 \\
30\end{array}$ \\
\hline$D E \cdot 1$ & 34 & 3.536 & 569 & 6.344 & 2 & 7 & 1 & 1 & 131 & 4.875 & 2 & 1 & 2 & 0 & 1 & 1981 & 21 \\
\hline EABS & 86 & 4.452 & 4493 & 8.410 & 1 & 3 & 1 & 1 & 128 & 4.852 & 2 & 3 & 2 & 1 & 1 & 1984 & 24 \\
\hline FAST & 29 & 3.382 & 268 & 5.591 & 1 & 8 & 2 & 1 & 2250 & 7.719 & 1 & 1 & 2 & 0 & 1 & 1996 & 36 \\
\hline External Tank & 985 & 6.893 & 74453 & 11.218 & 2 & 0 & 0 & 0 & 1 & 0.000 & 1 & 0 & 0 & 2 & 2 & 1981 & 21 \\
\hline Galileo Orbiter & 1170 & 7.065 & 2755 & 7.921 & 2 & 6 & 4 & 4 & 134 & 4.898 & 2 & 2 & 3 & 2 & 1 & 1989 & 29 \\
\hline GEMINI & 3219 & 8.077 & 7344 & 8.902 & 4 & 1 & 3 & 2 & 1 & 0.000 & 1 & 3 & 2 & 2 & 2 & 1965 & 5 \\
\hline GRO & 413 & 6.022 & 13448 & 9.507 & 1 & 3 & 1 & 1 & 512 & 6.238 & 2 & 3 & 3 & 1 & 1 & 1991 & 31 \\
\hline HEAO-1 & 193 & 5.263 & 2593 & 7.861 & 1 & 1 & 1 & 1 & 6 & 1.792 & 2 & 3 & 3 & 1 & 1 & 1977 & 17 \\
\hline Hawkeye & 9 & 2.177 & 58 & 4.060 & 3 & 2 & 1 & 2 & 0.2 & -1.609 & 2 & 1 & 2 & 0 & 1 & 1974 & 14 \\
\hline IUS & 1085 & 6.990 & 7227 & 8.886 & 3 & 0 & 0 & 2 & 64 & 4.159 & 1 & 3 & 2 & $\mathbf{3}$ & 1 & 1982 & 22 \\
\hline LANDSAT- 1 & 185 & 5.219 & 1375 & 7.226 & 2 & 2 & 1 & 1 & 15000 & 9.616 & 2 & 3 & 3 & 1 & 1 & 1972 & 12 \\
\hline Lewis & 30 & 3.395 & 463 & 6.138 & 2 & 5 & 1 & 3 & 2000 & 7.601 & 1 & 3 & 3 & 1 & 1 & 1997 & 37 \\
\hline Lunar Orbiter & 411 & 6.019 & 394 & 5.976 & 3 & 7 & 1 & 1 & 50 & 3.912 & 1 & 3 & 3 & 2 & 1 & 1966 & 6 \\
\hline Lunar Prospector & 30 & 3.399 & 327 & 5.790 & 2 & 3 & 1 & 3 & 3 & 1.099 & 1 & 1 & 1 & 1 & 1 & 1997 & 37 \\
\hline Lunar Rover & 135 & 4.905 & 509 & 6.232 & 1 & 5 & 0 & 2 & 1 & 0.000 & 1 & 0 & 2 & 1 & 2 & 1971 & 11 \\
\hline Magsat & 20 & 3.003 & 168.0 & 5.124 & 1 & 6 & 1 & 1 & 320 & 5.768 & 2 & 3 & 1 & 0 & 1 & 1979 & 19 \\
\hline Magellan & 615 & 6.422 & 2554 & 7.845 & 1 & 2 & 1 & 1 & 268 & 5.591 & 2 & 3 & 3 & 1 & 1 & 1989 & 29 \\
\hline Mariner-10 & 294 & 5.682 & 936 & 6.842 & 2 & 11 & 1 & 1 & 117 & 4.762 & 1 & 3 & 3 & 1 & 1 & 1973 & 13 \\
\hline Mariner-4 & 329 & 5.796 & 516 & 6.246 & 2 & 4 & 1 & 2 & 16 & 2.773 & 1 & 3 & 1 & 1 & 1 & 1964 & 4 \\
\hline Mariner-6 & 563 & 6.334 & 705 & 6.558 & 2 & 4 & 1 & 2 & 16 & 2.773 & 2 & 3 & 3 & 1 & 1 & 1969 & 9 \\
\hline Mariner-8 & 425 & 6.052 & 1069 & 6.974 & 2 & 5 & 1 & 1 & 132 & 4.883 & 2 & 3 & 3 & 3 & 1 & 1971 & 11 \\
\hline Mars Global Surv. & 117 & 4.766 & 1275 & 7.151 & 2 & 3 & 2 & 3 & 85 & 4.443 & 2 & 3 & 1 & 3 & 1 & 1996 & 36 \\
\hline Mars Observer & 324 & 5.780 & 851 & 6.746 & 1 & 9 & 1 & 1 & 85 & 4.443 & 2 & 3 & 3 & 3 & 1 & 1992 & 32 \\
\hline Mars Pathfinder & 184 & 5.214 & 1502 & 7.315 & 1 & 0 & 1 & 2 & 6 & 1.792 & 2 & 1 & 3 & 1 & 1 & 1996 & 36 \\
\hline NEAF & 116 & 4.757 & 1480 & 7.300 & 1 & 5 & 2 & 1 & 26 & 3.258 & 2 & 3 & 3 & 3 & 1 & 1996 & 36 \\
\hline OMV & 701 & 6.553 & 12811 & 9.458 & 1 & 6 & 2 & 2 & 972 & 6.879 & 2 & 3 & 2 & 3 & 1 & 1985 & 25 \\
\hline OSO-8 & 185 & 5.220 & 1037 & 6.944 & 3 & 1 & 1 & 1 & 128 & 4.852 & 2 & 2 & $\mathbf{3}$ & 1 & 1 & 1975 & 15 \\
\hline Pioneer Venus & 114 & 4.735 & 760 & 6.633 & 5 & 5 & 1 & 1 & 2 & 0.693 & 2 & 1 & $\mathbf{3}$ & 1 & 1 & 1978 & 18 \\
\hline Pioneer-10 & 303 & 5.714 & 422 & 6.045 & 2 & 5 & 4 & 2 & 16 & 2.773 & 2 & 1 & 2 & 9 & 1 & 1972 & 12 \\
\hline SAMPEX & 74 & 4.298 & 125.4 & 4.832 & 1 & 2 & 1 & 1 & 3000 & 8.006 & 2 & 3 & 1 & 0 & 1 & 1992 & 32 \\
\hline Shuttle Orbiter & 12343 & 9.421 & 153522 & 11.942 & 4 & 8 & 3 & 0 & 192 & 5.257 & 2 & 3 & 3 & 3 & 2 & 1981 & 21 \\
\hline S-IS & 3492 & 8.158 & 197363 & 12.193 & 1 & 0 & 0 & 2 & 1 & 0.000 & 2 & 3 & 0 & 2 & 2 & 1968 & 8 \\
\hline S-11 & 3723 & 8.222 & 71255 & 11.174 & 1 & 0 & 0 & 2 & 1 & 0.000 & 2 & 3 & 0 & 2 & 2 & 1968 & 8 \\
\hline S-IVB & 1893 & 7.546 & 32419 & 10.386 & 1 & 0 & 0 & 2 & 1 & 0.000 & 2 & 3 & 0 & 2 & 2 & 1968 & 8 \\
\hline Skylab OWS & 2507 & 7.827 & 68001 & 11.127 & 1 & 2 & 1 & 0 & 50000 & 10.820 & 2 & 0 & 0 & 1 & 2 & 1973 & 13 \\
\hline SMS-1 & 140 & 4.939 & 406 & 6.006 & 3 & 0 & 1 & 1 & 1 & 0.000 & 2 & 1 & 2 & 1 & 1 & 1974 & 14 \\
\hline SAB & 691 & 6.538 & 37698 & 10.537 & 1 & 2 & 0 & o & 1 & 0.000 & 1 & 3 & 0 & 0 & 2 & 1981 & 21 \\
\hline SSM & 800 & 6.685 & 11233 & 9.327 & 3 & 4 & 1 & 3 & 1024 & 6.931 & 2 & 3 & 1 & 2 & 2 & 1990 & 30 \\
\hline Surveyor & 1287 & 7.160 & 647 & 6.472 & 1 & 5 & 1 & 2 & 1 & 0.000 & 2 & 3 & 1 & 2 & 1 & 1966 & 6 \\
\hline SWAS & 35 & 3.554 & 373 & 5.922 & 1 & 5 & 2 & 1 & 1800 & 7.496 & 1 & 3 & 3 & 2 & 1 & 1995 & 35 \\
\hline TDRSS & 667 & 6.503 & 3391.1 & 8.129 & 4 & 4 & 1 & 1 & 300000 & 12.612 & 2 & 3 & 2 & 1 & 1 & 1983 & 23 \\
\hline TIROS-M & 128 & 4.852 & 435.1 & 6.076 & 1 & 3 & $i$ & 1 & 2 & 0.693 & 2 & 2 & 2 & 0 & 1 & 1970 & 10 \\
\hline TIROS-N & 64 & 4.152 & 836.0 & 6.729 & 3 & 3 & 1 & $i$ & 2662 & 7.887 & 2 & 3 & 2 & 0 & 1 & 1978 & 18 \\
\hline TOMSEP & 56 & 4.017 & 432 & 6.068 & 1 & 2 & 1 & 1.5 & 202 & 5.308 & 1 & 3 & 2 & 1 & 1 & 1996 & 36 \\
\hline TOPEX & 201 & 5.304 & 3154 & 8.056 & 1 & 3 & 1 & 1 & 1024 & 6.931 & 2 & 3 & 3 & 1 & 1 & 1992 & 32 \\
\hline UARS & 303 & 5.714 & 7385 & 8.907 & 3 & 3 & 1 & 1 & 512 & 6.238 & 2 & 3 & 3 & 3 & 1 & 1991 & 31 \\
\hline Viking Lander & 1315 & 7.181 & 1908 & 7.554 & 2 & 6 & 4 & 1 & 16 & 2.773 & 2 & 3 & 0 & 1 & 1 & 1975 & 15 \\
\hline Viking Orbiter & 886 & 6.787 & 1941 & 7.571 & 2 & 5 & $i$ & 1 & 2116 & 7.657 & 2 & 3 & 3 & 3 & 1 & 1975 & 15 \\
\hline VOYAGER & 502 & 6.218 & 1410 & 7.251 & 2 & 5 & 4 & 1 & 115 & 4.745 & 2 & 3 & 3 & 1 & 1 & 1977 & 17 \\
\hline$x-34$ & 177 & 5.176 & 13925 & 9.541 & 2 & 3 & 0 & $i$ & 1 & 0.000 & 1 & 3 & 0 & 0 & 1 & 1999 & 39 \\
\hline
\end{tabular}


A small value of $C p$ indicates that the model is relatively precise (has small variance) in estimating the true regression coefficients and predicting future responses. Models with considerable lack of fit have values of $C p$ larger than $p$. Using the $C_{p}$ criteria, all regressions below with $C_{p} \leq($ Vars +1$)$ are acceptable
(Vars +1 because the Vars value shown in the statistical output does not count the constant and thus 1 must be added to Vars to equal $\mathrm{p}$ ). All equations with 4 or more variables are indicated by the $C_{p}$ criterion to be promising.

Exhibit 3: Best Subsets Regression.

Response is LnCost

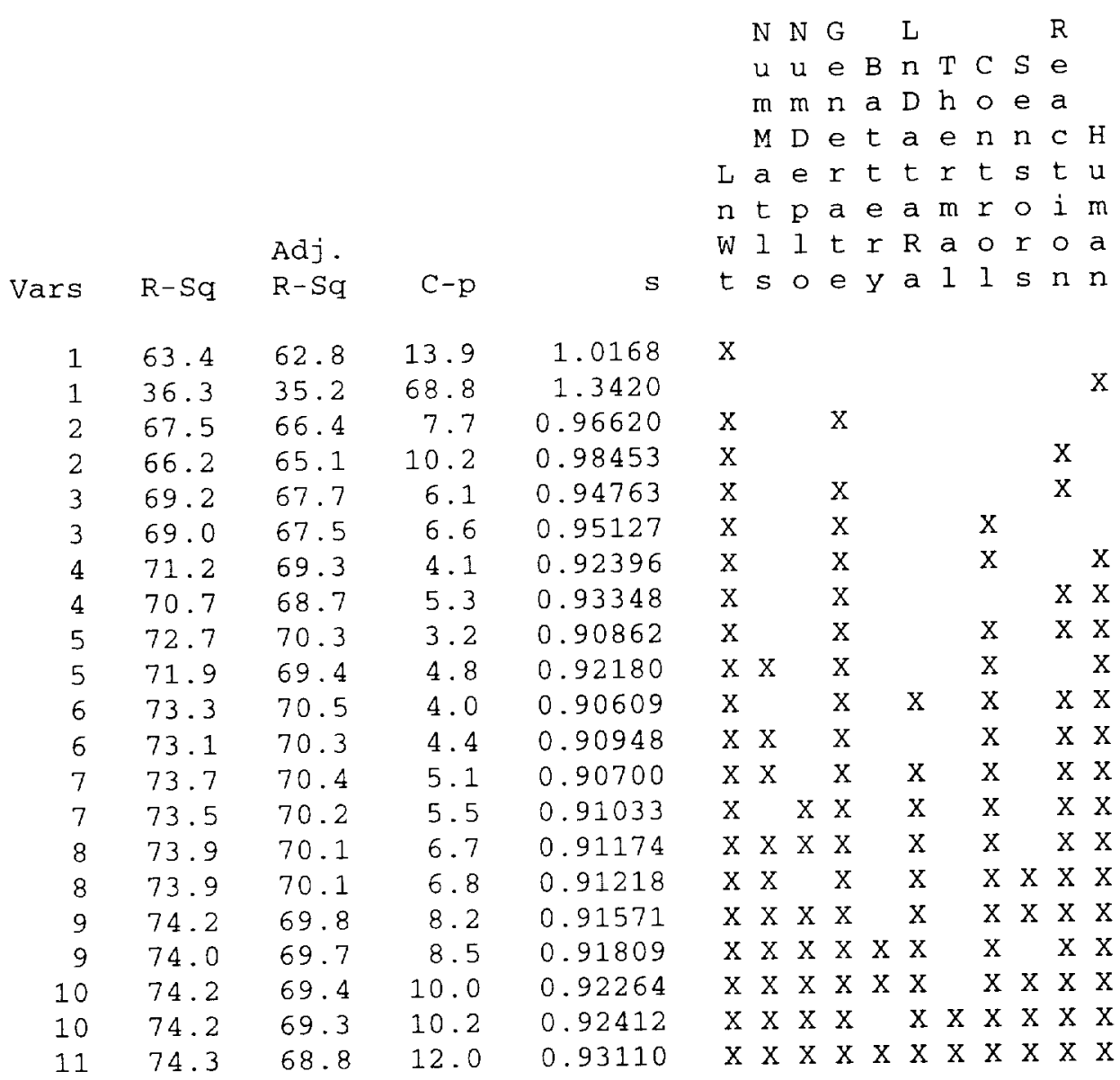

Because $C_{p}$ indicated that all equations with 4 or more variables are promising, a regression was first performed with all 10 variables. The results of that analysis, shown in Exhibit 4, indicate that the CC\&DH data rate (abbreviated as InDataRate) and the type of GN\&C sensors (abbreviated as Sensors) have negative slopes (i.e. increasing the requirement results in lower cost). This result is nonsensical from an engineering point of view. Thus these two variables were dropped form the regression. Also, from Exhibit 4, it can be observed from the value of the p coefficients that four other variables have poor significance. These include the variables Thermal, NumDeploy, Battery and NumMatls. These variables were actually carefully excluded one at a time while observing the impact on the overall $\mathrm{R}$ squared statistic and the value of the other individual predictor $\mathrm{p}$ values. As each variable was dropped, previous variables that had been dropped up to that step were re-introduced. This re-introduction included LnDataRate and Sensors to see if the sign reversal problem corrected itself but this was not the case. In no cases were the re-introduced variables sustained in terms of improving the CER.

In the end, the best subset CER selected, shown in Exhibit 5, included 5 variables: Dry $L n W t$, Generate, Control, Reaction and Human. This is actually an adequate CER for space missions with an $R$ squared 
Exhibit 4. Full Variable Regression Analysis.

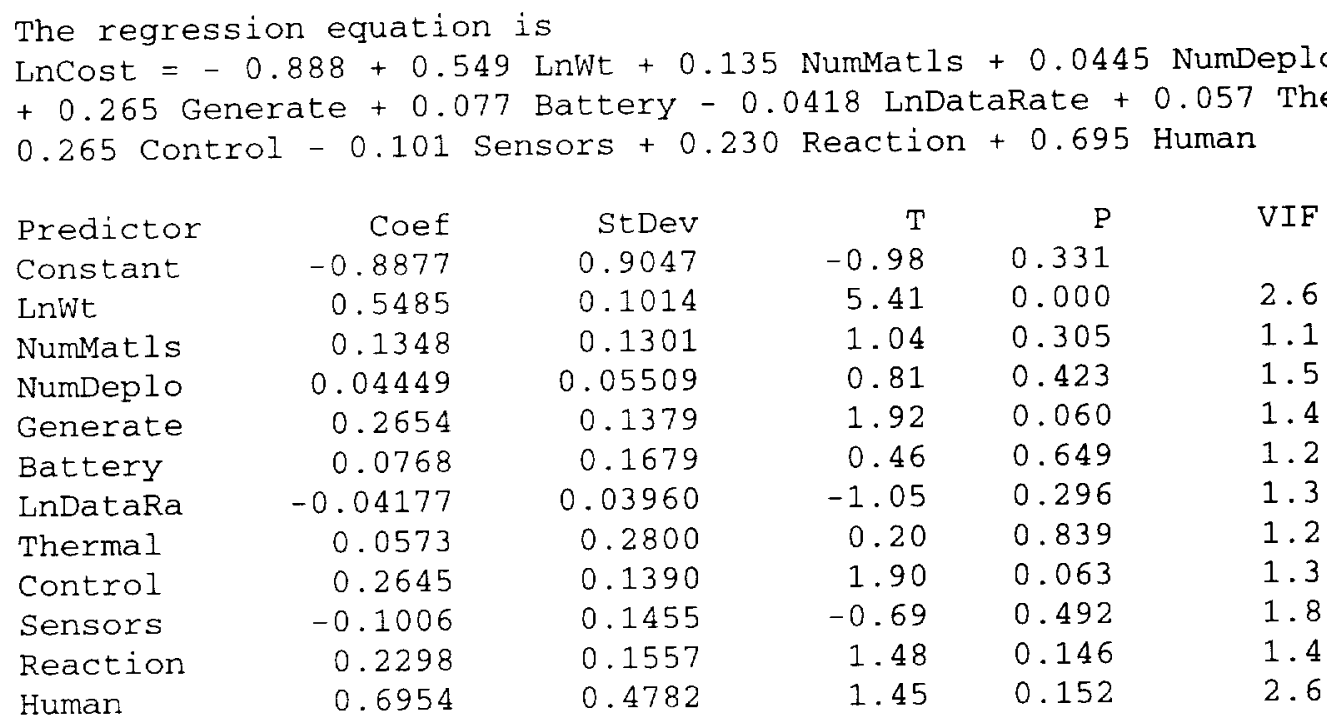

Analysis of Variance

$\begin{array}{lrrrrr}\text { Source } & \text { DF } & \text { SS } & \text { MS } & \text { F } & \text { P } \\ \text { Regression } & 11 & 130.104 & 11.828 & 13.64 & 0.000 \\ \text { Residual Error } & 52 & 45.081 & 0.867 & & \\ \text { Total } & 63 & 175.185 & & & \end{array}$

Exhibit 5. Final Best Subset of Technical Variables Regression Equation.

The regression equation is

LnCost $=-0.834+0.526$ LnWt +0.302 Generate +0.269 Control +0.244

Reaction + 0.943 Human

$\begin{array}{lrrrrr}\text { Predictor } & \text { Coef } & \text { StDev } & \text { T } & \text { P } & \text { VIF } \\ \text { Constant } & -0.8344 & 0.5618 & -1.49 & 0.143 & \\ \text { LnWt } & 0.52603 & 0.09383 & 5.61 & 0.000 & 2.3 \\ \text { Generate } & 0.3024 & 0.1189 & 2.54 & 0.014 & 1.1 \\ \text { Control } & 0.2688 & 0.1300 & 2.07 & 0.043 & 1.2 \\ \text { Reaction } & 0.2441 & 0.1407 & 1.73 & 0.088 & 1.2 \\ \text { Human } & 0.9427 & 0.4153 & 2.27 & 0.027 & 2.0 \\ \text { S }=0.9086 & \text { R-Sq }=72.78 \quad \text { R-Sq(adj) }=70.38 & \end{array}$

Analysis of Variance

$\begin{array}{lrrrrr}\text { Source } & \text { DF } & \text { SS } & \text { MS } & \text { F } & \text { P } \\ \text { Regression } & 5 & 127.300 & 25.460 & 30.84 & 0.000 \\ \text { Residual Error } & 58 & 47.884 & 0.826 & & \\ \text { Total } & 63 & 175.185 & & & \end{array}$


correlation of $70.3 \%$ (acceptably good for space cost CERs), with an $F$ test $p$ value of 0.000 indicating that the overall equation is acceptable and with all independent variable $p$ values less than 0.10 (indicating a confidence level of better than $90 \%$ that these variables do drive cost)

\section{Introduction of a Time Variable}

At this point, armed with a CER that fairly adequately predicts the cost of space missions, the time variable, abbreviated as Years-1960, is introduced into the regression to see if the predictive power of the resulting CER is an improvement. The results of that regression are shown in Exhibit 6.

Exhibit 6. Regression Analysis With Technical Variables and Time.

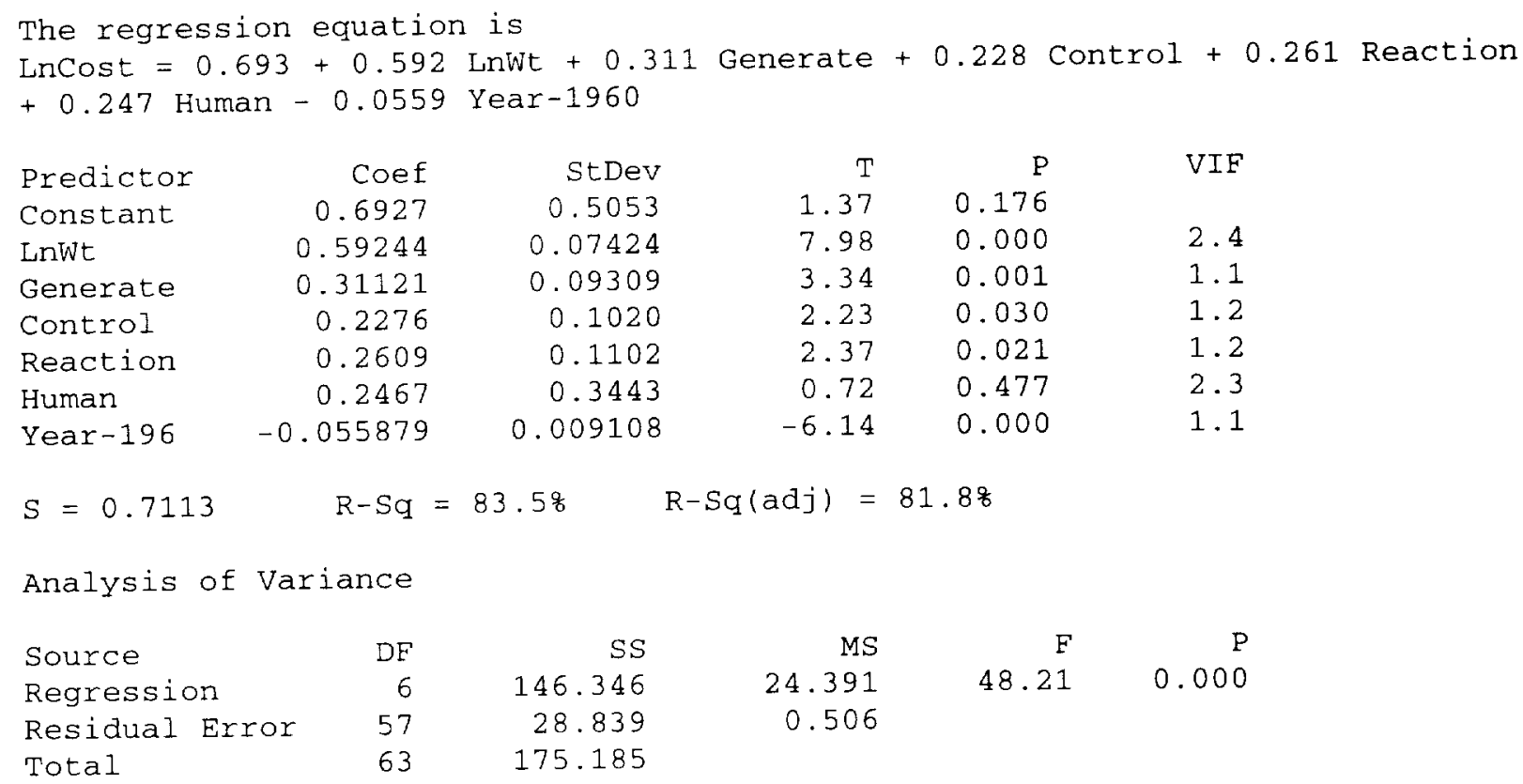

Exhibit 7. Regression Analysis With Technical Variables (Less Human) and Time.

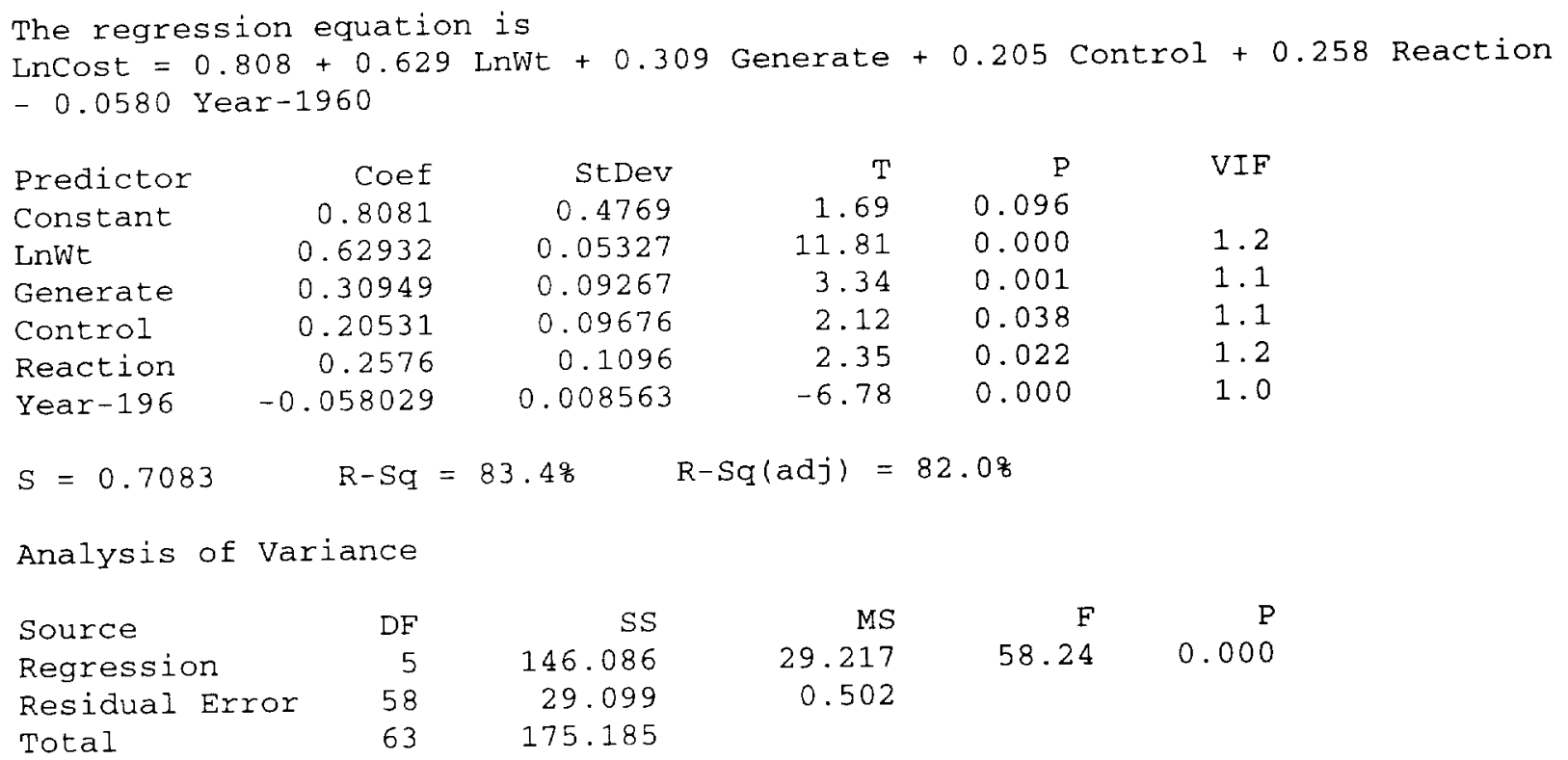


Exhibit 8. Analysis of Residuals
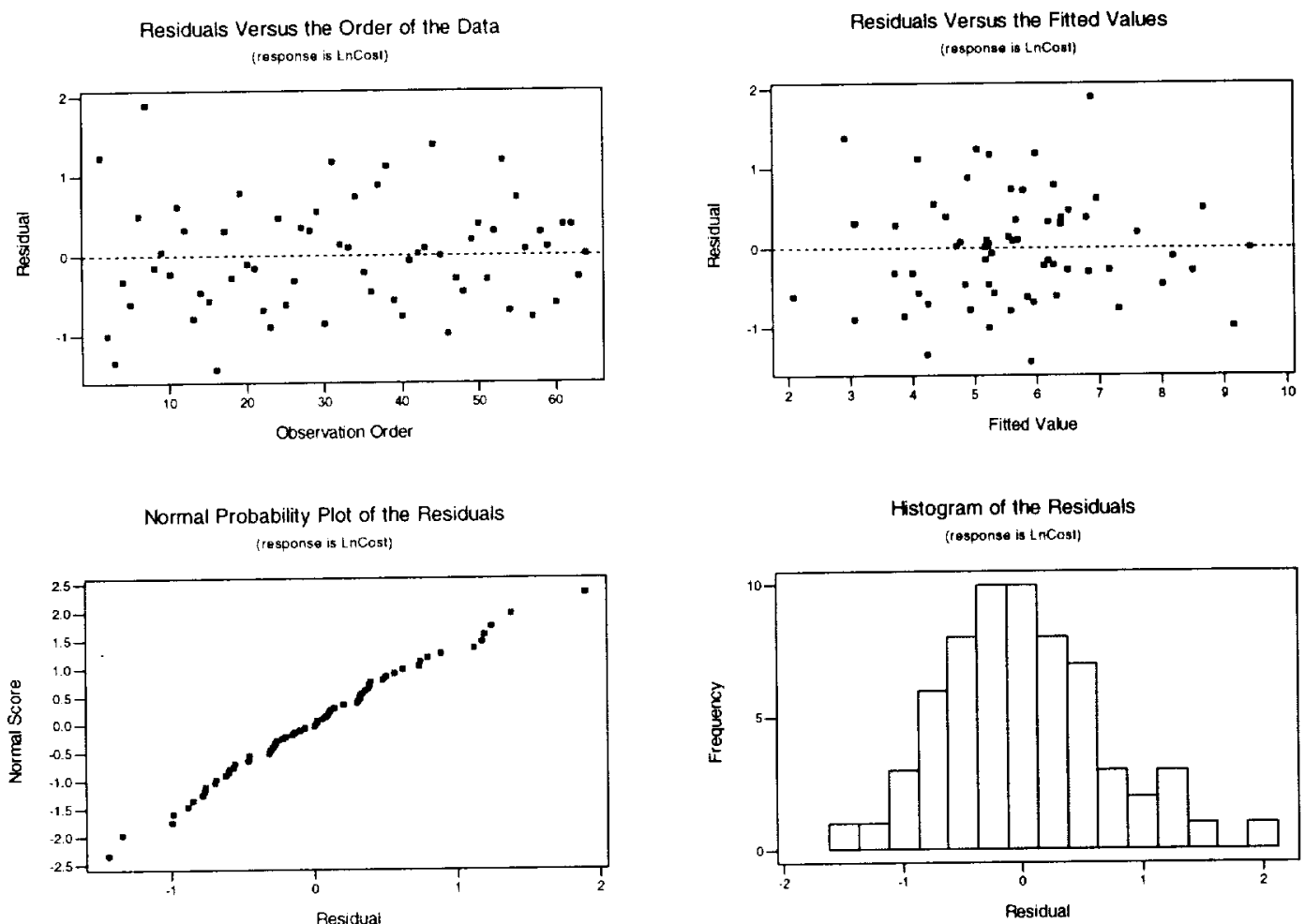

Interestingly enough, this regression yiclds a CER with an improved $\mathrm{R}$ squared value of $81.8 \%$ (significantly better than the CER with technical variables only which had an $\mathrm{R}$ squared of $70.3 \%$ ). The variable Year-1960 is seen to be very significant with a $\mathrm{p}$ value of 0.000 and with a negative slope indicating improvements in cost over time. Though very heartening, a more careful examination of Exhibit 6 also indicates that one variable, Human, now has a troubling $p$ value of 0.477 . The regression was thus run again, dropping Human to see if the CER is improved. The results of this are shown in Exhibit 7.

Omitting Human results in a better CER since it has fewer variables, a slightly higher $\mathrm{R}$ squared and essentially unchanged $p$ values for the independent variables. It can also be argued that several of the remaining variables are explaining the contribution of Human including weight $(L n W t)$ because human rated projects tend to have larger weights, Generate (via the fuel cells selection because only human missions have used fuel cells, and Control (since all Human missions have been 3 axis controlled. So it could well be that the variable Human is not offering any additional explanatory power once the above variables are

included. As a final check of this regression, an analysis of residuals was performed resulting in the graphs in Exhibit 8.

As can be observed, all of the residual plots are acceptable. The residuals versus order of the data shows no non-random time related effects in the residuals. The residual versus fitted values shows the desired random pattern on either side of zero with no reason to suspect that the error is not random. The normal probability plot of the residuals generally forms a straight line indicating normally distributed residuals. Finally, the histogram of the residuals has essentially the desired bell curve shape around a mean of zero.

\section{Conclusions and Observations}

The final regression equation of

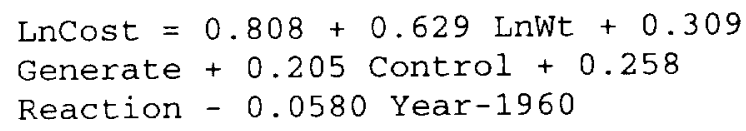

indicates, through the negative coefficient on the variable Year-1960, that cost is decreasing each year for reasons in addition to the weight, type of power 
generation, type of attitude control or type of reaction control. Because the previous regression without Year1960 did a creditable job of predicting cost, the hypothesis that there are some other effects beyond these major technical variables that are contributing to a decreasing cost trend cannot be rejected. This analysis does not, of course, prove that these other effects are due to engineering management factors. However, the initial qualitative analysis presented in this paper at least suggests that engineering management improvements and could be the reason for improved cost effectiveness.

\section{Recommendations For Further Study}

It is recommended that further study be undertaken to collect additional engineering management data on specific past NASA projects in the database used here. This data could then be used to rank the individual projects leading to a quantitative scale for individual projects over time. Further regression analysis could then be accomplished to determine if the engineering management factors are a stalistically significant driver in the cost of space projects.

The major obstacle to such a continued study will be the research required to obtain credible and documented information on engineering management culture sufficient for a NASA confident quantitative ranking. Preliminary research by the author into the NASA archives has turned up considerable documentation on the management practices of individual projects. It is for this reason that the author has some confidence that such a study is feasible.

The benefits of introducing engineering management variables into the mix of independent variables used for space systems cost analysis would be significant. These additional variables help reduce residual variance in the CERs and cost models. It would also serve to highlight the importance of engineering management practices on the cost outcome of projects and serve to give project managers quantitative information about the likely outcome of choices they have in how to manage their projects.

\section{References}

Hamaker, Joseph W., The Faster, Better, Cheaper Approach To Space Missions: An Engineering Management Assessment (1999)

NASA/Air Force Cost Model 99 (NAFCOM99), Version 6.1, Science Applications International Corporation, Huntsville, Alabama, (June 2000)

\section{About the Author}

Joseph W. Hamaker received his M.S. in Engineering Management from the University of Alabama in Huntsville (UAH). He holds a B.A. degree in Economics from UAH and a B.S. degree in Industrial
Engineering from Tennessee Technological University. $\mathrm{He}$ has completed course work for the Ph.D. program in Engineering Management at UAH and is currently working on his dissertation. He is employed by the NASA Marshall Space Flight Center in Huntsville, AL where he is Manager of the Engineering Cost Office. 